\title{
Brasil isn't only disease: Juscelino Kubitschek and the search for a new image of Brazil
}

\section{Gilberto Hochman}

Professor, History of Health and Science Unit, Oswaldo Cruz Foundation, Brazil

Translated by Rachel Tenhaaf

Now we are no more [...] the immense hospital of the phrase, a phrase that became historical because it was true, as per the clairvoyant observation of Miguel Pereira.

-Juscelino Kubitschek, candidate to the presidency of the Republic, 1955.

In March 1955, Juscelino Kubitschek de Oliveira, doctor and former mayor of Belo Horizonte (1940-45), left his post as governor of the state of Minas Gerais in order to become a candidate for presidency of the Republic. He proposed to modernize the country by deepening its industrialization and national integration. Elected October 3, 1955, by a coalition led by the Partido Social Democrático (PSD), he took office January 31, 1956, for a five-year term. His optimistic economic and political plan featured the slogan, "Fifty years in five," and included a series of goals and his meta-synthesis Brasilia, the new capital that would be built in the interior of the country. This plan also reinforced the role of the State as planner and promoter of development and national integration (Benevides 1979; Gomes 2002; Lafer 2002).

Although health was not a central part of his governing proposal, during the electoral campaign of 1955, Kubitschek presented a plan for that sector as well. This plan signaled changes in health priorities. In the end, Kubitschek asserted, Brazil would no longer be only disease (Kubitschek 1955a, 32). Miguel Pereira (1922) had stated on October 11, 1916, that "Brazil is still an immense hospital;" the phrase had become key to interpreting Brazil and was, therefore, employed in Candidate Kubitschek's discourse. Pereira's statement became the call-to-arms in the national movement for rural sanitation promoted by the 
Liga Pro-Saneamento de Brasil (1918-1920). Under the leadership of Belisário Penna, this organization brought together intellectual elites, professionals, and politicians, and mobilized them for a reform in health and sanitation that would give the State the instruments necessary to overcome this dramatic diagnosis (Castro Santos 1985; Lima and Hochman 2005; Hochman 2012; Lima 2013). Rejecting racial and climatic determinism, these doctors and intellectuals explained the mobilization by referring to the omnipresent rural endemicsespecially the "unholy trinity": ancylostomiasis (hookworm disease), Chagas disease, and malaria-as well as to the absence of public power in the interior as explanations for the country's backwardness and its population's lack of productivity. In this way, the identity of diseased country would not become an epitaph for Brazil, but instead a denunciation of its abandonment of the diseased population of the interior. This criticism was linked to a therapeutic policy that offered the possibility of rehabilitating the interior through public health measures.

Four decades later, Kubitschek sought to imbue the relationship between disease and nation with this same positive connotation in his proposals for the nation's development, both in his health policies and his first steps as presidentelect. In his opinion, Brazil had overcome "pestilent diseases" (like yellow fever and the bubonic plague), and the new government should dedicate itself primarily to combating the "mass diseases" such as tuberculosis, leprosy, gastrointestinal illnesses, and rural endemics that debilitated and rendered nonproductive millions of Brazilians (Kubitschek 1955a, 4-5). He also warned that the country should have already begun acting against chronic-degenerative diseases, that is, "diseases of the developed world," including cancer and heart disease. Although similar to the general goals of the social-hygienist movement of the First Republic, Kubitschek's plan articulated an optimistic vision of the country's future, reinforcing the idea that the health of the Brazilians was already better than it had been, that the diseases that once afflicted them had faded away at the beginning of the twentieth century. For him, the unhealthy picture painted by both Miguel Pereira's diagnosis in 1916, as well as the proposals of the rural sanitation movement, had now been altered by the actions taken in the public health sector and the advances in medicine. $\mathrm{Ku}$ bitschek's program was aligned with the so-called "sanitary optimism" that was evidenced in the two decades following the Second World War (Garret 1995, 39-40). During the Cold War, this optimism, together with the availability of new preventative measures and therapies-insecticides, antibiotics, sulfas, and anti-malarials - compelled governments, bilateral cooperating agencies, and international organizations to formulate and implement health policies in order to control and even eradicate diseases in what was then called the "underdeveloped world" (Farley 2004; Cueto 2007a; Packard 2007).

This article analyzes Kubitschek's health policies from his 1955 electoral 
campaign as well as the discourse it established using Miguel Pereira's phrase as its foundation. It places this discourse alongside interpretations of the country as ill and the clamor for more state activism in the field of public health and education. Generally, this piece argues that, although the reality of sanitation in Brazil had indeed changed, offering new challenges and demanding different answers from the public, the stamp of disease, misery, and illiteracy associated with the interior remained indelible in the candidate and doctor's discourse. This mark continued to be echoed in the public health policies of Kubitschek as president. The national and international contexts that marked his government were much more diverse than those that shaped Miguel Pereira's discourse. The "mass diseases", especially the rural endemic diseases, remained on the Brazilian public health agenda along with the governmental diagnosis of neglect of the populations of the backlands. Juscelino Kubitschek's public health platform was a political and electoral program directed toward a specialized public of doctors, sanitarians, and politicians. It reveals the Brazilian president's perception of public health policies: its proposals, contradictions, and compromises. By giving an optimistic spin to Brazil's sanitary transformation from the reality presented by doctors in the 1910s, Kubitschek reaffirmed and updated the interpretive key of "Diseased Brazil" inaugurated by the public health reform movement of the First Republic. Now, however, it came with new perspectives and objectives.

\section{The question of public health and development}

In general, the historiographical production on the 1950s and, in particular, on Kubitschek, has focused on the ideology of development, its political and economic aspects, and international relations (Cardoso 1977; Toledo 1977; Benevides 1979; Bielschowsky 1988; Vizentini 1996; Dulci 1999; Lafer 2002; Gomes 2002), along with the construction of Brasilia (Moreira 1998). Several biographies describe Kubitschek's personal characteristics (Couto 2001; Bojunga 2001) beyond his own prolific narrative on his presidency and projects (Kubitschek 1974). The minor importance of health compared to other areas of public policy (Pena 1977) has led to few academic works dedicated to the topic of health, especially during the period known as the national-development period. The few exceptions are mostly in the field of public health studies and that of economics and public health (Braga and Paula 1981; Escorel 2000), in addition to works by a few historians, such as Paiva (2006), Campos (2006) and Kropf (2009). In public health specifically, this production has reinforcedexcessively in my opinion - the dichotomy between "developmentalist public health" (sanitarismo desenvolvimentista) and "campaign-based public health" (sanitarismo campanhista) as models and perspectives for state action that ap- 
peared as counterparts in the 1950s and the beginning of the 1960s (Braga and Paula 1981; Labra 1988; Escorel 2000, Escorel and Teixeira 2008). In general, for these authors, the power behind the idea of "developmentalist public health" was that the health of the population would depend, fundamentally, on the country's level of development. In consequence, the only sanitary actions that could have an impact would be those that were integrated into a national project of economic development. In this model, economic development would supposedly stimulate the same in the health of the population. Also, the emphasis would be on the integration of services and on decentralization. This is the opposite of the "campaign-based public health" which, generally speaking, emphasized vertically centralized sanitation interventions that were directed by technology and focused on resolving specific sanitary problems apart from social and environmental changes. According to this perspective, changes in sanitary conditions would help break through the obstacles to development. This viewpoint, one that returned at the beginning of the century, reaching its zenith in the sanitary actions of the Rockefeller Foundation, became the dominant paradigm in the period following World War II; it was classified by Packard and Brown (1997) as the "bounded biomedical conception" of health.

The studies on public health during this period signal that the doctor Mário Magalhães da Silveira and the parasitologist Samuel Barnsley Pessoa were the articulators of the ideas behind "developmentalist" axis and use their work as a point of reference along with a series of talks by Aramis Athayde, Minister of Public Health in the government of Café Filho (Athayde 1957; Labra 1988; Escorel 2000; Paiva 2006). The US origins and the actions of the Serviço Especial de Saúde Pública (Special Public Health Service) (SESP) made this organization a target for the criticism of the "developmentalists" (Campos 2006). The doctor and malariologist Mário Pinotti, Juscelino Kubitschek's Minister of Public Health from 1958 to 1960, is the figure who is highlighted as the best expression of the vertically- and technologically-oriented programs, especially those for the eradication of diseases (Hochman 2007; Silva 2008; Silva and Hochman 2011).

An analysis of the Kubitschek health platform and administration indicates that this polarization is artificial, at least until the end of the 1950s. It was constructed later through the bibliography of the field of public health, in light of the 1980's Brazilian health reform. These analyses came about as a result of the need to oppose emphatically the models of health established from the first government of President Getúlio Vargas to the course of public health and medical assistance after the civil-military coup in March 1964. They were eventually reproduced without critical examination. It is important to recognize that, in fact, this polarization occurred from the point of view of the ideas, and did not necessarily affect public policy in effect in the sector during the period that immediately preceded the military regime, in a politically and socially un- 
stable and radicalized environment. In the 1950s, the individuals who verbalized this polarization recognized the necessary and inseparable relationship between health and development with the differences beginning in the emphasis given to each element (Lima, Fonseca, and Hochman 2005). In that decade, criticism was not directed so much toward the "campaign-based model" itself as a form of organization (vertical and centralizing) but at the perspective that uncoupled medical-sanitary intervention from socio-economic development.

From the point of view of national politics, the relationship between health and development appeared, in some way, in all presidential messages after 1949, when President Eurico Dutra recognized that "the sanitary conditions of a country rigidly circumscribe its socio-economic development" (Brasil 1949, 127). The relationship between health, disease, poverty, and the need to break "the vicious circle of disease and poverty" and understand the "cost of disease and the value of health" (Myrdal 1952; Winslow 1955) were incorporated in the Brazilian debate by all its protagonists. Symptomatic of the centrality of this debate is the fact that the $5^{\text {th }}$ World Health Assembly (Geneva 1952) had as invited keynote speakers the Swedish economist Gunnar Myrdal and the US public health expert Charles-Edward Winslow, the designers and promoters of the principal thesis on the relationship between disease, poverty and underdevelopment (Myrdal 1952; Winslow 1955). ${ }^{1}$ In this same World Health Assembly, the prominent Brazilian public health doctors linked to the SESP, Manoel Ferreira and Ernani Braga, and the engineer Paulo de Assis Ribeiro, presented the paper, "The economic value of health" directly engaging in dialogue with the propositions of Myrdal and Winslow (Ribeiro, Ferreira, and Braga 1998). That their positions on public health were not as irreconcilable as has been presented in literature is suggested by the fact that one of the most important books from "developmentalist and reformist public health" proponent (and communist) Samuel Barnsley Pessoa, Ensaios médico-sociais (published in 1960), was dedicated to the person considered to be the icon of the vertical model and the campaigns of eradication: Mário Pinotti. ${ }^{2}$

What occurred throughout the 1950s was a slow shift of positioning and increased emphasis toward one of the sides of the relationship between public health and development. The leadership in this period was not from "developmentalist doctors" or ideologues. They came to prominence only at the beginning of the 1960s. Furthermore, while some of the principal voices in questions of Brazilian public health, such as Mário Pinotti, were involved in programs of

1. In a few words, Winslow outlined the problem this way: "Poverty causes disease and disease creates more poverty, in a vicious circle. Public Health is therefore a problem which is intimately related to the economic and social factors which has been made in a given community" (Winslow 1955, 106)

2. "To Mário Pinotti, whose work in the Ministry of Health contributed so much to the progress of medicine and the Health of the Brazilian people" (Pessoa 1978). 
disease control and eradication, they also started incorporating, in their writing and public speaking, more horizontal agendas such as nutrition, rural medical aid, and health programs for mothers and children. This is apparent in the book The Life and Death of the Brazilian (Vida e morte do brasileiro) (Pinotti 1959). As John Farley indicates, in the two decades following the Second World War, the efforts to increase the population's health and economic welfare can be seen as "pendulums" that swung between two extremes, not always with the same velocity or in ways that necessarily coincided:

1. Between the belief that controlling or eradicating communicable diseases was required in order to achieve socio-economic development and the conviction that, although control was necessary, socioeconomic development was a prerequisite for bettering public health.

2. Between the belief that campaigns against specific diseases should be vertically controlled and directed from the outside, and the belief that the campaigns against diseases should be horizontally directed in relation to a larger group of diseases and should establish a basic level of sanitary infrastructure.

3. Between the defenders of "development ideology" and the understanding that the international system creates and perpetuates underdevelopment and reproduces a permanent international inequality system (Farley 2014, 284-285).

From the end of the Second World War to the mid-1950s, international public health experts were convinced that the eradication of disease proceeded from development and was, in fact, a condition for it. They also believed that vertical campaigns organized with precise ends would be the best instruments to achieve this eradication. The certainty of a possible and rapid victory over infectious diseases, particularly "tropical diseases," was even proclaimed by the US Secretary of State, George Marshall (1948). In the field of development, the key discourses to shape ideas and international, national, and local practices (Escobar 1998; Love 1996; Rist 2002) focused on science and technology (and medicine) as fundamental in order for poor countries to gain access to the First World. This would also help these susceptible countries avoid populism and socialism.

When the Cold War and sanitary optimism converged, malaria was chosen as the perfect "economic disease" and became the prime focus of international and national attention during the period (Packard 1997; Packard, Brown 1997; Cueto 2007a). From 1957 onward, during the Eisenhower administration, malaria was the focus of US external politics. This emphasis was influenced by William Rostow's argument that augmenting direct aid to underdeveloped countries would generate wellbeing and spread North 
American values, thereby associating modernization and anticommunism (Tulchin 1988; Latham 2000; Cueto 2008). This perspective marked the action of cooperating US agencies involved in international health initiatives (Cueto 2008). In 1958, Juscelino Kubitschek, mid-term, would become the spokesperson for demanding a greater commitment from the US with regard to development in Latin America, a demand that would culminate in the Operation Pan-America (Silva 1992; Vizentini 2004). Thus, the eradication of malaria came to be considered the precondition for development, because it would free the population for work and the territories for agriculture and other economically productive activities.

Marcus Cueto $(2007 ; 2008,36-37)$ indicates that public health served as the instrument for consolidating North American safety within the international scene. The underlying intention was to elevate the quality of life in rural populations in underdeveloped countries, thus creating consumers and reinforcing the idea of economic progress within a context that was marked by a discourse that signaled "communism" and "malaria" as conditions that "enslaved" individuals.

Candidate Kubitschek expressed, in large part, this "strict conception" of the relationship between health, development and sanitary optimism, all of which dominated in the 1950s. Some proposals attempted to continue the public health initiatives begun during Kubitschek's term as governor of Minas Gerais (Quatro anos . . 1959). However, some of the same "pendulums" proposed by Farley had already started to swing, either due to international conditions or national contexts. Thus, it is also possible to read in Kubitschek's health program a concern for integrating health services and introducing new medical-sanitary problems.

\section{Rural endemic diseases as a priority of Kubitschek's government}

Kubitschek's public health programs were marked by the same idea of Brazilian development that accompanied his electoral campaign and, afterwards, his speeches and actions as president (Kubitschek 1955b). All signs indicate that this program was written by Mário Pinotti, who directed the Malaria National Service (Serviço Nacional de Malária - SNM) starting in 1942 and who was Minister of Public Health for a very brief period during the second government of Vargas. ${ }^{3}$ Pinotti gained scientific and political prestige beginning in the

3. It is highly probable that many parts of the program were written by Pinotti himself. There are passages identical to those that appear in the work and writings of Pinotti in the 1950s. The part regarding malaria in the program is based on the study Pinotti and René Rachou conducted in 1955 that was published the following year in the Brazilian Journal of Malariology and 
1940s and had ties to the Social Progressive Party (Partido Social Progressista) (PSP). This party was part of the parliamentary coalition that supported $\mathrm{Ku}-$ bitschek and controlled the Ministry of Public Health during almost his entire time in office. ${ }^{4}$ The main argument expressed in this document of fifty-seven pages was that the public health problems of the Brazilian population had incapacitated them, not allowing them to take on the urgent and necessary task of national development. The association between public health and development was presented as a complex question that could be reduced by choosing only one part of the equation: "emphasis on the betterment of the population's public health conditions" versus "public health as a result of the country's development." These proposals reflect the arguments that were already made by Myrdal and Winslow regarding the applicability of a "vicious circle of disease and poverty" as well as the necessity of breaking this circle; they are also present in Kubitschek's candidacy speeches that, even while emphasizing the public health dimension, never cease to recognize the necessity of changing the population's public health conditions.

This more general perspective that held together his public health proposals gained a special legitimacy because Kubitschek positioned himself not only as a politician but also as a doctor who understood the "suffering of our people" and, above all, who knew what was happening in the interior of Brazil due to his experience as governor of Minas Gerais between 1951 and 1955 (Kubitschek 1955a, 3). From his positions as doctor and politician native to the interior as well as governor of a state that included a significant part of the innumerable sanitary and social problems of Brazil, the president diagnosed his country's public health and proposed eighteen goals that would help overcome what he considered to be the major public health problems of the Brazilian people. ${ }^{5}$

Tropical Disease (Revista Brasileira de Malariologia e Doenças Tropicas), published by SNM until 1956, the year in which it began to be edited by the National Department for Rural Endemic Diseases (Departamento Nacional de Endemias Rurais) (Rachou 1956).

4. Kubitschek's first minister of Public Health was the doctor, professor, scholar, and congressman Mauricio de Medeiros (January 1956-July 1958) from the PSP of São Paulo. He was replaced by Pinotti (July 1958-August 1960). It is important to remember that Adhemar de Barros, the leader of the PSP, and the former mayor of the city of São Paulo, ran against Kubitschek and received the third highest number of votes in 1955. After the latter was elected, the PSP became part of the party coalition that supported his presidency.

5. This characteristic of presenting himself as a doctor is clear in Kubitschek's speeches as governor of Minas Gerais and as president. When speaking on medical and public health issues, or for an audience of doctors or public health professionals, he presented himself as a member of the medical community, "which I will never cease to be, although I am not currently practicing." In another passage, he said that he was still " $30 \%$ a doctor" (" $30 \%$ de professional"), because politics had not steered him away from medicine. See, for example, Quatro anos . . 1959, 103, and "No Colégio Brasileiro de Cirurgiões ao ensejo da abertura do X Congresso Interamericano e V Congresso Brasileiro de Cirurgia" (Kubitschek 1958). For this point see also the book of Érico Silva Muniz (2013). A biography that celebrates the medical career of Juscelino Kubitschek was published by Fernando Araújo (2002). 
This identity, the one which Kubitschek legitimizes himself by referring to "diseases of the interior", reinforces the ongoing dualism between coastal and interior present in the social and political thinking in Brazil and determinant in the medical-hygienist discourse of the 1910s (Lima 2013). Ignorance, preconceptions, and the abandonment of the interior by the government of the "men of the coast," continued to appear explicative of the country's sanitary problems. In some passages of his program, Kubitschek denounces the Brazilian urban ignorance regarding the men and women in the interior, a denunciation that is expressed in two different ways, both prejudicial. On the one hand, there is the negative view of the population as indolent (Kubitschek 1955a, 7), and on the other there is an admiration for the resistance capacity and heroism attributed to those in the interior (Kubitschek 1955a, 20). In both cases, these distorted conceptions historically handicapped the population when it came to governance and also consigned them to being forgotten by the urban middle classes. The separation of these two Brazils and the negative imagery appears in the "couches and hard floors," that Kubitschek uses to criticize those who, from their materially comfortable positions, cannot understand the difficulties of rural families. The figure he depicts is that of the tourist who, from his comfortable cabin on a boat, observes the inhabitants of the San Francisco and defines them as lazy (Kubitschek 1955a, 8). In opposition to the positivist discourse, the public health program alludes to Euclides da Cunha (1944, originally in Portuguese 1902) and his character, the Northeastern cowboy (the vaqueiro).

For Kubitschek, the phrase "the peasant is, above all, strong" had been distorted by urban Brazil. This affirmation from Euclides da Cunha would not be a tribute but rather a "protest against the indifference with which the poorly civilized Brazil leaves behind the pure and true Brazil" (Kubitschek 1955a, 20). His proposal was to revisit this "inoperative and lyrical glorification" of the suffering of the peasants by extending labor legislation to the rural population and amplifying the reach of public health and aid policies.

Generally speaking, the recuperation of the population's public health can be understood, on its most basic level, as a reestablishment of its capacity for work and the achievement of income. In the words of the candidate: "we will cure the country and we will have healthy men who are capable of undertaking the task of developing the country" (Kubitschek 1955a, 5). The tragic circle that associated poverty with malnutrition, precarious living situations and disease should be broken in order to produce a Brazilian worker who was healthy and productive. Housing and nutritional policies were offered as governmental actions that, outside of the institutional realm of public health, would be essential in order to overcome the country's precarious sanitary state.

During his term as governor of Minas Gerais, Kubitschek sought to incentivize diversification and modernization of the farming and mining industries, which were associated with the motto "energy and transport" that came from 
his predecessor Milton Campos (Dulci 1999). In his final speech as governor and candidate to the presidency, Kubitschek (1955b, 90) declared that he would give "absolute priority to the industrialization of the staple foods." From the middle of the 1940s onward, the food supply had begun to occupy more space on the agenda of the intellectuals tied to the field of nutrition such as Josué de Castro as well as on the social agenda of the governments. In March 1955, President Café Filho created the National Campaign for School Nutrition (Campanha Nacional de Alimentação Escolar). The subjects of hunger and undernourishment were often mentioned in Kubitschek's speeches where they were strongly associated with questions of health and sanitation. The solution to the problem of nutrition in the Brazilian people was offered as the key to economic development, which is to say, modernizing agriculture and livestock production, fomenting the industry of staple food production, adding transport and specific infrastructure, such as silos and refrigerators (Kubitschek 1955a, 4-7, 39-42).

The central theme of the public health program was facing the so-called mass diseases that "caused suffering, underutilized or killed enormous multitudes of Brazilians" (Kubitschek 1955a, 4). These infectious and parasitic diseases were the principal objects of consideration for the candidate. There is a clear displacement of the hierarchy of "Brazilian diseases" that was present in Miguel Pereira's speeches and in those established immediately after by the sanitation movement of the First Republic: "the unholy trinity." 6 Of the great rural endemics cited in 1916, malaria and ancylostomiasis would leave the top of the list, although the problem of verminosis would be much distinguished from the rest. The focus would land on tuberculosis, leprosy, Chagas disease, leishmaniasis, yaws, schistosomiasis, endemic goiters and trachoma, some of which were prevalent in Minas Gerais and had been the focus of Kubitschek's attention while he was governor (Quatro anos . . 1959). In 1953, at the opening of the $10^{\text {th }}$ Brazilian Congress on Hygiene (X Congresso Brasileiro de Higiene) that took place in Belo Horizonte, sponsored by Kubitschek (then governor of Minas Gerais), Mário Pinotti announced a "new era" in public health. This new era would be due to technological advances produced by the Second World War. This was the moment to undertake "national crusades" against "endemic diseases and the epidemics that assailed Brazil in Miguel Pereira's time" (SBH, 1953, xv).

The big announcement in 1955 concerning malaria: in a double move, malaria was explicitly considered to be a problem that had almost been overcome and, at the same, retired from the group of diseases that would be top priority for governmental action, especially in the rural areas. For Kubitschek (1955a,

6. "... disabled, weak, exhausted, by ancylostomiasis and malaria, broken and destroyed by Chagas disease, corroded by syphilis and by leprosy, devastated by alcoholism, sucked dry by hunger, clueless, abandoned, without ideals or education ... (Pereira 1922). 
p.15-16), malaria had already been "expelled" from Brazil and would no longer be a large national problem, a fact which he attributed to the long and persistent work of Brazilian malariology.

In May 1955, the $8^{\text {th }}$ World Health Assembly that met in Mexico City approved the urgent resolution to initiate a program to eradicate malaria on a global scale, coordinated by WHO and with the support of the United Nations Children's Fund (UNICEF). One year earlier, the Pan American Sanitary Bureau (PASB) recommended the same measures be taken at the regional level. ${ }^{7}$ The diagnosis and proposals of Kubitschek as candidate and the recommendations of the international health organizations, therefore, did not converge; malaria became the principal focus of international public health while the candidate and future president of Brazil removed it from the top position on the national agenda.

Given the large number of cases of diseases, the size of Brazilian territory and its extensive frontiers with various South American countries, the country was a key piece in any international attempt to combat malaria. From 1941 on, the year of the creation of the National Malaria Service, there were systematic attempts undertaken with the objective of controlling the disease, an endemic in various regions. They created organizational structures, developed research activities; medicines and insecticides were tested, produced and distributed. They ran public health campaigns and introduced innovative prophylactics and therapies, as well as the free distribution of cloroquinated table salt, as proposed by Mário Pinotti. This occurred in regions such as Amazonia where the massive fumigation of DDT would be harmless due to the population dispersion, its nomadism and the precariousness of housing (Pinotti 1953). The cloroquinated salt strategy would remain known as the "Pinotti method" and lifted its proponent to the level of international public health figure (Hochman 2008; Silva and Hochman 2011).

In this process, under the leadership of Pinotti, a quite organized group of malariologists emerged and became internationally recognized for their achievements in Brazilian public health (Hochman 2008; Silva and Hochman 2011). The interests of these rising specialists cemented Candidate Juscelino Kubitschek's arguments regarding malaria. For him, the endemic malaria was under control and had ceased to be a large national health problem, thanks to the efforts of those Brazilian malariologists. Therefore, the public health program was a political piece of empowerment and tribute to Pinotti and his colleagues, and also a strong indicator of the strength of their control over the agenda and the health institutions in the Kubitschek administration. It is not surprising that the candidate's public health program was prefaced and probably written by Mário Pinotti. He would become the first director of the $\mathrm{Na}$ -

7. On the decision of the $\mathrm{WHO}$ and the PASB and regarding the Malaria Eradication Program, see Packard 1998; Siddiqi 1995; and Cueto 2007a; 2007b. 
tional Department of Rural Endemic Diseases (DNERu). This department was created in March 1956, immediately after Juscelino's election. After this, Pinotti would become Minister of Health between 1958 and $1960 . .^{8}$ In this moment of "notable conquests" in Brazilian public health, Kubitschek signaled Pinotti as the one responsible for controlling malaria in Brazil as well as naming him the successor in the lineage begun by Oswaldo Cruz that included Carlos Chagas and Belisário Penna, placing him in a type of pantheon of Public Health (Kubitschek 1955a, 53).

It is true that, beyond the stakes and the rhetoric, at the beginning of the decade, even presidential speeches had begun to indicate the reduction of malaria due to the actions to control it. The shocking number of eight million infected (almost one-seventh of the Brazilian population), that began to be promulgated and repeated beginning in 1949, was always cited by Candidate Kubitschek in order to celebrate the reduction, a reduction considered to be "spectacular," by $97 \%$ in one decade (Kubitschek 1955a. 15-16, 54). ${ }^{9}$ In this way, for the candidate, one of the rural endemics that had been used to characterize the country as ill in the first decades of the twentieth century had ceased to be the most grave public health problem. Tying the optimism of the Brazilian malariologists to the electoral moment, he promised, then, to complete the work that had already begun, eliminating it if he were elected (Kubitschek 1955a, 17, 54). In his opinion, in 1955, "malaria actually ceased to be the most grave public health problem in Brazil!” (Kubitschek 1955a,17).

Once the plague and yellow fever had been routed and they had learned the "lessons of malaria" (Kubitschek 1955a, 15-16), the principal goals for public health proposed by the candidate were oriented toward the elimination of the rest of the rural endemic diseases and toward the fight against tuberculosis and leprosy. ${ }^{10}$ This was considered a viable possibility precisely because of the vigorous development of the chemical and pharmaceutical industries due to the Second World War, emphasizing residual insecticides, anti-malarials and antibiotics. For the candidate, "science and modern technology gave men, above all governments, new and efficient, power and sometimes immediate prophylactic and therapeutic resources, ones that are easily applicable, for combating

8. For a brief biography of Mário Pinotti, see Hochman, 2007. For more general aspects of his medical-political trajectory see Silva, 2008; 2015; Hochman 2008; Silva and Hochman 2011.

9. This number of cases, mentioned in various presidential speeches after 1945, did not come from either research or national censuses. It appears to have been the result of a calculation made by João de Barros Barreto (1949, 7-10) in 1940. He used the formula John A. Sinton had developed for India, applying it to the Brazilian case. The information regarding this drastic reduction can be found in Rachou (1956). These elevated numbers are similar to those of Belisário Penna $(1918,95)$ who calculated that $40 \%$ of the Brazilian population had been a victim of malaria in 1918.

10. Smallpox, one of the principal public health problems for Brazil in the First Republic, is not even mentioned. It would reappear on the agenda during Kubitschek's government in a program for global eradication proposed by the Soviet Union in 1958 (Hochman 2009, 238-242). 
the mass diseases" (Kubitschek 1955a, 5). This indicates the fact that, in Brazil, there were already instruments to eliminate yaws (injectable penicillin), trachoma (sulfates), and endemic goiters (iodized salt), among other endemics present in the interior of Brazil and associated with poverty. These instruments would simplify the public health campaigns and change the role of medicine in public health, which would begin to "exercise the mission of create directives, oversee and orient" (Kubitschek 1955a, 5). Specialized and well-trained teams would be enough to reach the objective of eliminating rural endemics given the simplification of therapeutic actions. As signaled in the case of yaws and also trachoma: "It is enough to give an injection ..." to liberate thousands of Brazilians who could "work for a Brazil that is in such need of work to be done" (Kubitschek 1955a, 25). The so-called "strict conception" of the relationship between health and development, associated with the vertical campaign model, appears here in the belief that "magic bullets"11 were available to hit a precise target, the pathogen, without affecting or needing to change the rest of the diseased organism and its environment, which is to say the conditions of life that produced it (Muniz 2013).

The formation of human resources for a public health reconfigured for new instruments and techniques was a challenge and deserved a special space in the medical candidate's program. The lack of technicians, doctors, nurses, dentists, and nutritionists, their concentration in cities, and the inexistence of a system wholly devoted to sanitary services were obstacles to overcome in order to guarantee the end of the scourge of mass diseases, along with the absence of demographic and sanitation statistics (Kubitschek 1955a, 9-10). The installation of insecticide and pharmaceutical factories for public health campaigns was another action considered to be necessary, as well as a goal to be achieved in "our plan for economic development" (Kubitschek 1955a, 56). In this sense, the candidate also associated public health and economic development by linking the improvement of public health and nutrition to the development of the chemical and pharmaceutical industry oriented toward human health, agriculture and livestock production.

Chagas disease is emblematic of this stricter perspective. Kubitschek recognized that the disease was directly linked to the precariousness of housing in the interior of the country, because the transmitter (barbeiro or "barber bug") was sheltered in huts (cafuas). However, he considered the betterment of housing to be a long-term project: in the end, "it is impossible to immediately give the millions of rural workers housing equal to that in the city, along with the security, the comfort and the hygiene that they deserve" (Kubitschek 1955a, 18). In this way, combating the barber bug with insecticide, as achieved from

11. "Magic bullet," originally defined by the German bacteriologist Paul Ehrlich, refers to the idea that certain therapeutic products would fight only their specific target, leaving the rest of the organism's cells intact. 
1950 onward, would be the immediate recourse, efficient and available to contain the disease. Eliminating this and other endemic diseases would make it possible for the population and territories to be incorporated in the process of development, attaining a better quality of life.

The candidate's public health program, however, reveals other conceptions, indicating that some of the "pendulums" were already moving on the health-development axis. Kubitschek's diagnosis and proposals were organized according to diseases and specific problems as well as their solutions, through focused methods, but there also appeared more horizontal and integrated concepts: nutrition, housing, maternity and infancy care, care for the elderly, leisure and sports, worker's health, and medical-sanitary assistance. The candidate for the presidency's concerns were on par with the demands of the country that, despite having $70 \%$ of its population in rural areas, was also undergoing an intense process of urbanization. This process modified old health problems and produced new ones. In terms of "Brazilian diseases," Juscelino (Kubitschek 1955a, 28) called attention "to a new health problem that is not only our own but of all civilized people:" cancer. Its importance in the diagnostic picture under transformation would reveal, once again, the country's dualities because this would be the disease of developing countries that had already destroyed mass diseases. Poliomyelitis would appear as the new target for public health, especially after the outbreaks in the capital at the beginning of the 1950s. It does not go unnoticed that, after mentioning in his program the various endemic diseases that were being propagated in rural Brazil, as well as other "mass diseases", and before mentioning this new agenda for urban Brazil, Kubitschek introduced, as a transition in his arguments and his proposal, a section titled "Brazil is not only disease" (Kubitschek 1955a, 32-33).

The topics of sanitation and housing (water supply, sewage networks, and housing) and of labor (health insurance, industrial hygiene, and retirement pensions) are clearly emphasized in Kubitschek's electoral document, along with the necessity of improving and extending medical-sanitation aid (health centers, jobs, maternity leave, programs for school lunches, and sanitary education) to the $20 \%$ of the population that, according to him, was without any aid. It is symptomatic that the candidate recognized that achieving these objectives would not be possible solely through sanitary and medical services but would also need to be shared with other governmental departments. Along with doctors and nurses, professionals of various fields such as engineers, psychologists, nutritionists, architects, sociologists and economists would also be required (Kubitschek 1955a, 12). However, despite signaling all of these aspects, the same federalized centralization of health in the political and administrative sphere that had deepened during Vargas's first term (1930-1945) would be maintained throughout the democratic period. In a few cases, such as 
that of psychiatric aid, Kubitschek indicated the necessity for decentralization at the municipal and state levels.

With his rhetoric and optimism, the candidate concluded his health plan affirming that he was convinced the country could solve its largest health problems by taking advantage of "new sanitary weapons;" he also listed the targeted diseases and eighteen goals for his five-year term, declaring them "easy to achieve in five years of hard work" (Kubitschek 1955a, 53). Many of those mentioned were related to specific diseases (13) and the majority were associated with the rural and/or impoverished communities, a fact that concerned the candidate (Table 1 offers a synthesis of the principal goals and the chosen methods to achieve them). The commitment they entailed indicated a desire to interiorize federal public health since they predicted that for each sanitary action taken in the urban center, "a tiny Medical-Sanitary Unit will begin to service the nucleus of the population in the furthermost area of Brazil" (Kubitschek 1955a, 57). In this way, as through his entire program, he reinforced the idea that "Brazil is not only contained in its metropolis and the capitals of each state," but it also "palpitates" in the vaqueiro and the seringueiro of the country's interior (Kubitschek 1955a, 19-20, 25-28, 57).

\begin{tabular}{|c|c|c|}
\hline Target disease & Main objective & Public health instruments \\
\hline Trachoma & Eradication & Sulfonamides and antibiotics \\
\hline Yaws & Eradication & Penicillin \\
\hline Malaria & Eradication & DDT and anti-malarial drugs \\
\hline Schistosomiasis & Control & $\begin{array}{l}\text { Elimination of snail breeding grounds, } \\
\text { disinfection, and drugs }\end{array}$ \\
\hline $\begin{array}{l}\text { Endemic goiter and } \\
\text { other diseases related } \\
\text { to deficiencies }\end{array}$ & Elimination & $\begin{array}{l}\text { Enforcement of the law mandating io- } \\
\text { dization of table salt (1953); public } \\
\text { nutrition programs }\end{array}$ \\
\hline Chagas disease & Eradication & Residual insecticides \\
\hline Leishmaniasis & Extinction & Residual insecticides and treatment \\
\hline Verminosis & Control & Basic sanitation \\
\hline Leprosy & Control & Sulfonamides and TB I \\
\hline Cancer & Assistance & $\begin{array}{l}\text { Installation of study centers, treatment } \\
\text { and diagnosis }\end{array}$ \\
\hline Mental illnesses & Assistance & $\begin{array}{l}\text { Extension and decentralization of psy- } \\
\text { chiatric assistance, increasing the } \\
\text { number of beds and professionals }\end{array}$ \\
\hline Tuberculosis & Combat/assistance & $\begin{array}{l}\text { BCG, active search for the sick, home } \\
\text { care, dispensaries, and ambulatory } \\
\text { treatments }\end{array}$ \\
\hline Poliomyelitis & Combat/assistance & $\begin{array}{l}\text { Production and administration of the } \\
\text { Salk vaccine }\end{array}$ \\
\hline
\end{tabular}

Source: Kubitschek 1955a, 53-57.

Note: The categories and terms from the Health Program of 1955 were adapted. 


\section{Final considerations}

When we turn our eyes toward our man in the interior we must not see only a diseased man.

-Juscelino Kubitschek, candidate for the presidency of the Republic, 1955.

The dialogue established with Miguel Pereira originated from the statement that Brazil had already overcome an important part of its health problems. This occurred because medicine and the State had availed themselves of new prophylactic and therapeutic instruments that had emerged after the Second World War. This optimism was expressed not only in the development of Brazilian coastal areas (littoral) but also in that of the interior, in which we should not only see "a diseased man", "an immense hospital", but also a healthy, available, hard-working and hopeful population. This would be the new image of Brazil, one that, without hiding its evils, had proven its capacity to create and incorporate scientific and technological innovation to the benefit of public health, as had occurred with malaria. With this, no longer would "attitudes of pessimism and negativism in regards to the future of Brazil" be permitted (Kubitschek 1955a, 32).

The Brazilian public health agenda continued to focus on rural endemic diseases, now with an added conviction that they could be concretely defeated as was the case with malaria. Kubitschek's health platform had to acknowledge the sanitary problems of the country's interior but, at the same time, commit to overcoming them. This commitment, one that would have been able to be taken on by any candidate in the presidential election, was, at that time, considered by the reigning sanitary optimism of the decade to be a viable one. The sanitation campaigns that would eliminate mass diseases would also remove the obstacles that impeded the incorporation of the rural worker in the process of capitalist economic development. In his insistence on negating it, the candidate ended by reaffirming the strength of the metaphor of disease as the identity of Brazil.

In an exceedingly coherent way, Kubitschek's first important decision in regards to the field of public health, made immediately after he assumed office in January 1956, was to create, in March, the DNERu. This united various national service sectors that had been created in 1941 to deal with the interior diseases such as malaria, leishmaniasis, Chagas disease, plague, brucellosis, yellow fever, schistosomiasis, ancylostomiasis, filariasis, hydatidosis, endemic goiter, yaws and trachoma. Various research centers in the Ministry of Health, including the Institute for Malariology were united to form the National Institute of Rural Endemic Diseases (INERu), subordinate to the DNERu. This last became the principal public health institution during Kubitschek's government; it was 
implemented by Mario Pinotti and dominated by the malariologists. This was the concretization of Juscelino's post-electoral prioritization of combating rural diseases. This was reinforced by his handing over control to those who had conceived of this goal and were considered to be successful in regards to controlling malaria in Brazil.

The end of the Serviço Nacional de Malaria and its incorporation into the new department confirmed the diagnosis that malaria was not the worst sanitary problem and, for that reason, no longer needed its own institution. The same vision that made possible the successes in combating malaria would be applied to the actions against the rest of the rural diseases. This decision clashed with the recommendation of the PASB and WHO that countries create specific, autonomous institutions, each with their own budgets for the eradication of malaria. It also went against the tendency of other Latin American countries to create national services to fight malaria in the middle of the 1950s (Cueto 2007a; Hochman 2008; Alvarez 2010).

Conversely, the new public health agenda-chronic-degenerative diseases, medical care for urban workers, aging, leisure-indicated that Brazil was more developed and urban than a country with mass diseases. In this discourse surrounding the interpretation of Brazil, the reaffirmation of the coastal-interior dualism as well as the possibility of overcoming it, are present. In this case, for Kubitschek, who would later be acclaimed as the "Euclidean president," the crucial theme was the abandonment of the rural population by the men of the city; this rural population had been waiting for centuries for action. According to Kubitschek (1955a, 33), it would no longer be possible to signal this "divorce in the blood and the energy of Brazil."

The urgent and most general response the candidate advocated for moved from fighting to the elimination of rural endemic diseases, but it also transcended them: it signaled towards development. In this way, "it was not enough to fight diseases". Instead, putting a hoe, a symbol of routine and backwardness, in the hands of the now-redeemed peasant, would be tantamount to "a crime against Brazil" (Kubitschek 1955a, 33). Instead, they would need a "machine", which is to say the modernization of agriculture. In this sense, for Juscelino Kubitschek, if he were to achieve his goals, Miguel Pereira's phrase would be history not in 1955 but rather at the end of his presidential term in office.

The DNERu was the realization of the goals to eliminate rural endemics and, in fact, some sanitation campaigns, such as those that fought yaws and endemic goiter, were organized in 1956 and implemented from 1957 onward. Both were considered successful by the end of Kubitschek's presidency (Muniz 2013). In December 1960, one month before he completed his five-year term, the DNERu encouraged a meeting to evaluate its thirteen sanitation campaigns that were underway. Published only in 1962, this evaluation indicated that the results were irregular across the rural health campaigns (DNERu 1962). An- 
other important event during Kubitschek's government was the first National Campaign against leprosy(a disease characterized as one of the "masses"), an event inaugurated in February 1959.

The major change in relation to Juscelino Kubitschek's 1955 diagnosis and health policy proposals would be in regards to malaria. In the middle of his term, the president experienced a grave economic crisis and serious funding problems that affected his development projects and his ability to build new capital. The US policy of cooperating on issues of public health, an important piece of the Cold War atmosphere, indicated it would offer financial assistance for fighting malaria only to countries that converted their programs of control into programs of eradication. In February 1958, in accordance with the US development agency, with the PASB and WHO, the Brazilian government created a Campaign for the Eradication and Control of Malaria (Campanha de Erradicação e Controle da Malária, CEM). This was tied to the DNERu, indicating a gradual conversion (that would only be finalized in 1965) along with a Working Group for the Control and Eradication of Malaria (Grupo de Trabalho de Controle e Erradicação da Malária, GTEM) that was coordinated by Pinotti, the then director of the DNERu. Changes in the national and international climate made malaria, an "almost extinguished" disease in 1955, return to the top of the Brazilian health agenda (Hochman 2008).

In his first message to the National Congress as president of the Republic, Juscelino Kubitschek clearly defined his prevailing view on the relationship between health and development:

... for many of these diseases that most afflict the population of underdeveloped countries, new discoveries in terms of therapy or prophylactics have made fighting it, and consequently a great reduction, or even elimination of it, independent of the problems of economic development and the high cost medical-sanitation apparatus (Brasil 1956, 187).

It is with this optimistic and modernizing perspective, which is to say in the possibility of realizing "fifty years in five," that we must understand such an electoral piece as Juscelino Kubitschek's health program was. He affirmed the possibility that, with innovations in prophylactics and treatments, "mass diseases" could be eradicated independent of the changes in the country's economic development. However, these "magic bullets" would not be sufficientor "were not enough to fight the diseases" (Kubitschek 1955a, 33) —which is to say, he recognized that development and modernization were fundamental factors in any health program. 


\section{Acknowledgements}

This text resulted from research financed by the National Council for Scientific and Technological Development (CNPq), and is a revised version of the article published in História, Ciências, Saúde-Manguinhos (Vol. 16, 2009) and of the chapter published in the book Patologias de la Pátria - Enfermedades, Enfermos y Nación en América Latina (Buenos Aires: Lugar Editorial, 2012), coorganized with Maria Silvia Di Liascia and Steven Palmer.

I would like to thank Alexandra M. Stern and the Latin American and Caribbean Studies of the University of Michigan for supporting the translation and for the initiative of publication of the article.

\section{References}

Araújo, Fernando. 2002. Juscelino Kubitschek, o médico. Belo Horizonte: RC Editora e Gráfica.

Athayde, Aramis. 1957. Conferências pronunciadas em 1955 pelo ministro Aramis Athayde. Río de Janeiro: Serviço de Documentação do Ministério da Saúde.

Barreto, João de Barros. 1940. Malária, doutrina e prática. Río de Janeiro: Editora A Noite.

Benevides, Maria Victoria. 1979. O governo Kubitschek: desenvolvimento econômico e estabilidade política, 1956-1961. Río de Janeiro: Paz e Terra.

Bielschowsky, Ricardo. 1988. Pensamento econômico brasileiro: o ciclo ideológico do desenvolvimentismo. Río de Janeiro: Ipea, Inpes (Serie PNPE, 19).

Bojunga, Cláudio. 2001. JK: o artista do impossivel. Río de Janeiro: Objetiva.

Braga, José Carlos de Souza, and Sergio Goes de Paula. 1981. Saúde e previdência: estudos de política social. Río de Janeiro, São Paulo: Cebes, Hucitec (Saúde em debate).

Brasil. 1949. Mensagem apresentada ao Congresso Nacional por ocasião da abertura da sessão legislativa de 1949 pelo General Eurico Gaspar Dutra, Presidente da República. Río de Janeiro, 1949. Río de Janeiro: Imprensa Nacional.

_ 1956. Oliveira, Juscelino Kubitschek de. Mensagem ao Congresso Nacional remetida pelo Presidente da República por ocasião da abertura da sessão legislativa de 1956. Río de Janeiro: Imprensa Nacional.

Campos, André Luiz Vieira. 2006. Politicas internacionais de saúde na era Vargas: o Serviço Especial de Saúde Pública, 1942-1960. Río de Janeiro: Editora Fiocruz (Coleção História e Saúde).

Cardoso, Miriam Limoeiro. 1977. Ideologia do desenvolvimento, Brasil: JK-JQ. Río de Janeiro: Paz e Terra (Coleção Estudos Brasileiros, 14).

Castro-Santos, Luiz Antonio. 1985. "O pensamento sanitarista na Primeira República: uma ideologia de construção da nacionalidade." Dados - Revista de Ciências Sociais, vol. 28, 2: 237-250.

Couto, Ronaldo Costa. 2001. Brasília Kubitschek de Oliveira. Río de Janeiro: Record.

Cueto, Marcos. 2007a. Cold War, Deadly Fevers: Malaria Eradication in Mexico, 19551975. Washington DC: Woodrow Wilson Center Press.

2007b. The Value of Health: A History of the Pan American Health Organization. Rochester: University of Rochester Press. 
-2008. "International Health, the Early Cold War and Latin America." Canadian Bulletin of Medical History, vol. 25, 1:17-41.

DNERUu. Departamento Nacional de Endemias Rurais. 1962. Combate a Endemias Rurais no Brasil (Relatórios dos Grupos de Trabalho reunidos em 1960 na cidade do Río de Janeiro). Brasilia: Ministério da Saúde.

Dulci, Otávio Soares. 1999. Política e recuperação econômica em Minas Gerais. Belo Horizonte: Editora UFMG.

Escobar, Arturo. 1998. La invención del Tercer Mundo: construcción y deconstrucción del desarrollo. Bogotá: Editorial Norma.

Escorel, Sarah. 2000. Saúde pública: utopia de Brasil. Río de Janeiro: Relume-Dumará (Arenas do Rio).

— 1822 a 1963: do Império ao desenvolvimento Populista." In Políticas e sistema de saúde no Brasil, edited by Lígia Giovanella, et al. Río de Janeiro: Editora Fiocruz/ Cebes, 333-384.

Farley, John. 2004. To Cast Out Disease: A History of the International Health Division of the Rockefeller Foundation (1913-1951). New York: Oxford University Press.

Garret, Laurie. 1995. A próxima peste: novas doenças num mundo em desequilíbrio. Río de Janeiro: Nova Fronteira.

Gomes, Angela Castro. 2002. O Brasil de JK. Río de Janeiro: Fundação Getúlio Vargas.

Hochman, Gilberto. 1998. A era do saneamento: as bases da política de saúde pública no Brasil. São Paulo: Hucitec, Anpocs.

_2007. "Mário Pinotti." In The Dictionary of Medical Biography, edited by William F. Bynum and Helen Bynum. Westport: Greenwood Press, vol. 4, 1013.

_.2008. "From Autonomy to Partial Alignment: National Malaria Programs in the Time of Global Eradication, Brazil, 1941-61." Canadian Bulletin of Medical History, vol. 25, 1:201-232.

-2009. "Priority, Invisibility and Eradication: the History of Smallpox and the Brazilian Public Health Agenda." Medical History, vol. 53, 2:229-252.

Kropf, Simone. 2009. Doença de Chagas, doença do Brasil: ciência, saúde e nação (19091962). Río de Janeiro: Editora Fiocruz.

Kubitschek, Juscelino. 1955a. Programa de saúde pública do candidato. São Paulo: L. Nicollini.

. 1955b. Sentido democrático de uma campanha. Belo Horizonte.

-1958. Discursos proferidos no primeiro ano de mandato presidencial, 1956. Río de Janeiro: Departamento de Imprensa Nacional, Serviço de Documentação da Presidência da República.

- 1974. Meu caminho para Brasília: [memórias]. Río de Janeiro: Bloch Editores. Labra, Maria Eliana. 1988. “1955-1964: o sanitarismo desenvolvimentista.” In Antecedentes da reforma sanitária, edited by Sonia Fleury Teixeira. Río de Janeiro: Escola Nacional de Saúde Pública, 9-36 (Textos de Apoio - Saúde).

Lafer, Celso. 2002. JK e o programa de metas (1956-61): processo de planejamento e sistema político no Brasil. Río de Janeiro: Editora da FGV.

Latham, Michael E. 2000. Modernization as Ideology: American Social Science and "Nation Building" in the Kennedy Era. Chapel Hill: The University of North Carolina Press.

Lima, Nísia Trindade. 1999. Um sertão chamado Brasil: intelectuais e interpretações geográfi cas da identidade nacional. Río de Janeiro: Revan. 
- Cristina O. Fonseca, and Gilberto Hochman. 2005. "A saúde na construção do Estado Nacional no Brasil: a reforma sanitária em perspectiva histórica.” In Saúde e democracia: história e perspectivas do SUS, edited by Nísia Trindade Lima, et al. Río de Janeiro: Editora Fiocruz.

— ina: El Brasil descubierto por el movimiento sanitarista de la Primera República." In Avatares de la medicalización en America Latina, edited by Diego Armus. Buenos Aires: Lugar Editorial, 50-69.

Marshall, George C. 1948. "Address of welcome by the honorable George Marshall, Secretary of State." Washington DC: Government Printing Office (Department of State, pub. 3246), vol. 2, 1-4. (Proceedings of the Fourth International Congress on Tropical Medicine and Malaria, Washington DC, May 10-18, 1948).

Moreira, Vânia Maria Losada 1998. Brasília: a construção da nacionalidade: um meio para muitos fi ns, 1956-1961. Vitória: Edufes.

Myrdal, Gunnar. 1952. "Economic Aspects of Health.” WHO Chronicle, vol. 6, 7-8:224242.

Packard, Randall. 1997. "Malaria Dreams: Postwar Visions of Health and Development in the Third World." Medical Anthropology, vol. 17, 3:279-96.

—. 1998. "No other logical choice': global malaria eradication and the politics of international health in the post-war era." Parassitologia, 40:217-229.

-2007. The Making of a Tropical Disease: A Short History of Malaria. Baltimore: Johns Hopkins University Press.

— ricizing a Cultural Model in International Health.” Medical Anthropology, vol. 17, 3:181-94.

Paiva, Carlos Henrique Assunção. 2006. "Samuel Pessoa: uma trajetória científi ca no contexto do sanitarismo campanhista e desenvolvimentista no Brasil." História, Ciências, Saúde - Manguinhos, vol. 13, 4:795-831.

Pena, Maria Valéria J. 1977. "Saúde nos planos governamentais." Dados - Revista de Ciências Sociais, 16:69-96.

Penna, Belisário. 1918. O saneamento do Brasil. Río de Janeiro: Editora dos Tribunais.

Pereira, Miguel. 1922 [1916]. "O Brasil é ainda um imenso hospital: discurso pronunciado pelo professor Miguel Pereira por ocasião do regresso do professor Aloysio de Castro, da República Argentina, em outubro de 1916." Revista de Medicina, vol. 7, 21:3-7.

Pessoa, Samuel Barnsley. 1978. Ensaios médico-sociais. 2nd. ed. São Paulo: Cebes.

Pinotti, Mário. 1953. "Novo método de controle da malária pelo emprego de medicamentos misturados ao sal de cozinha, utilizado na alimentação diária." Revista Brasileira de Medicina, Río de Janeiro, vol. 10, 4:241-6.

-1959. Vida e morte do brasileiro. São Paulo: Civilização Brasileira.

Quatro Anos ... 1959. Quatro anos no govêrno de Minas Gerais, 1951-1955: síntese das realizações do governador Juscelino Kubitschek de Oliveira. Río de Janeiro: Livraria J. Olympio.

Rachou, René. 1956. "Atual estratégia da luta contra a malária." Revista Brasileira de Malariologia e Doenças Tropicais, 4:3-25.

Ribeiro, Paulo Assis, Manoel José Ferreira, and Ernani Braga. 1998 [1952]. “Economic value of health." Revista Brasileira de Epidemiologia, vol. 1, 3:303-44.

Rist, Gilbert. 2002. The History of Development: From Western Origins to Global Faith. London: Zed Books. 
Siddiqi, Javed. 1995. World Health and World Politics: The World Health Organization and the UN System. London: Hurst \& Co.

Silva, Alexandra Melo e. 1992. "Desenvolvimento e multilateralismo: Um estudo sobre a Operação Pan-Americana no contexto da política externa de JK." Contexto Internacional, 14:209-239.

Silva, Renato da. 2008. Malária e desenvolvimento: a saúde pública no governo JK (19561961). Tesis de Doctorado. Programa de Pós-Graduação em História das Ciências e da Saúde, Casa de Oswaldo Cruz, Fundação Oswaldo Cruz, Río de Janeiro.

— mentoso, malária e saúde internacional (1952-1960).” Historia, ciências, saúdeManguinhos, vol. 18, 519-544.

SBH. Sociedade Brasileira de Higiene. 1953. Anais do X Congresso Brasileiro de Higiene. Belo Horizonte, 19 a 25 de outubro de 1952. Belo Horizonte: Imprensa Oficial do Estado de Minas Gerais.

Toledo, Caio Navarro. 1977. ISEB: fábrica de ideologias. São Paulo: Editora Ática.

Tulchin, Joseph S. 1988. “The United States and Latin America in the 1960s." Journal of Interamerican Studies and World Affairs, 30:1-36.

Vizentini, Paulo Fagundes. 1996. "A política externa do governo JK (1956-61)." In Sessenta anos de política externa brasileira, 1930-1990: crescimento, modernização e política externa, edited by José Augusto Guilhon Albuquerque. São Paulo: USP, Núcleo de Pesquisas em Relações Internacionais, vol.1, 231-251.

Winslow, Charles-Edward Amory. 1955. Lo que cuesta la enfermidad y lo que vale la salud. Washington: Organización Mundial de la Salud, Oficina Sanitaria Panamericana (Publicaciones Científi cas, vol. 16). 